\title{
KOULUTUKSEN \\ TULOSKESKUSTELU KIELIPELIEN KOHTAAMISENA
}

\author{
Perinteisesti kasvatuksen ja koulutuksen kieli on ollut pedagogista ja \\ sivistyksellistä. Viimeisen kymmenen vuoden aikana koulutuskeskusteluun \\ on tuotu markkinatalouden sävyttämää tehokkuuden ja tuottavuuden \\ sanastoa. Käsitteiden määrittely on kasvatuksen maailmassa kuitenkin \\ osoittautunut ongelmalliseksi. Artikkelissa tarkastellaan yhteiskunnallista \\ keskustelua koulutuksen tuloksellisuudesta filosofisella otteella. Tähän \\ ajankohtaiseen kysymykseen liittyvä problematiikka koskee kaikkia \\ koulutusasteita ja koulumuotoja esikouluista aikuiskoulutukseen.
}

\section{AINI ORAVAKANGAS}

K eskustelu koulutuksen tuloksellisuudesta on ollut käsitteellisesti hyvin hajanaiskeastaan ymmärtävät? Artikkelissa tartutaan tähän problematiikkaan Wittgensteinin kielipelin käsitettä hyväksi käyttäen. Empiirisenä lähtökohtana on 257 tekstiä käsittävä diskurssiaineisto, joka on kerätty mediasta, kasvatus- ja koulutusalan kirjallisuudesta sekä opettajien täydennyskoulutusten kurssimateriaaleista vuosina 1997-2002. Mediatekstit ovat uutisia, artikkeleita, kolumneja, haastatteluja, pakinoita, mielipidekirjoituksista ja television ajankohtaisohjelmia.

Esitän joitakin näkökulmia tekstiaineiston ja omien opettajakokemusteni perustalle rakennetusta filosofisesta tarkastelusta. Pohdiskelun teoreettiset ainekset nousevat Gadamerin filosofisesta hermeneutiikasta, myöhäis-Wittgensteinin arkikielen filosofiasta sekä Habermasin kommunikatiivisen toiminnan teoriasta.

Yhteiskunnallinen keskustelu koulutuksen tuloksellisuudesta on ollut monitahoista. Keskustelua on käyty politiikan ja hallinnon tasoilta oppilaitosten arkisiin kysymyksiin asti. On puhuttu säästöistä, oppimistuloksista ja laadusta, on puhuttu koulutuksen tasosta, arvioinnista ja kansainvälisestä kilpailukyvystä. Tuloksia on vertailtu kansainvälisellä ja kansallisella tasolla. Oppilaitokset ovat alkaneet kilpailla keskenään. Koulutuksen tuotantotehtävä, tulosten mitattavuus ja toiminnan julkisuus ovat korostuneet. Toisaal- la keskustelu sijoittuu osaksi talouden ja elinkeinoelämän suotuisan kehityksen diskurssia, toisaalla esiintyy paljon kriittistä puhetta tulosjattelun soveltuvuudesta kasvatuksen alueelle. Yhteiskunnallisessa keskustelussa esitetty koulutuksen kritiikki ja sen pohjalle rakennettu tuloksellisuuden vaatimus ovat alkaneet muokata oppilaitosten arkea ja opettajien työtä. Tulosten mitattavuus ja arvioin-

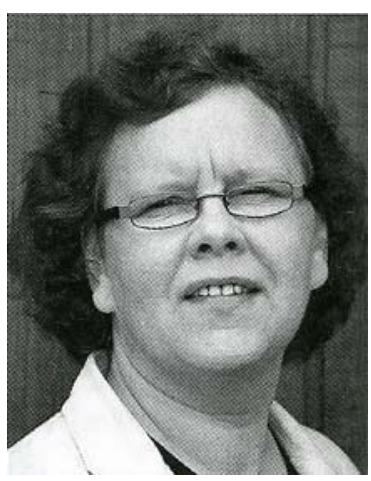

Aini Oravakangas titulosten hyödyntäminen ovat kuitenkin osoittautuneet monimutkaisiksi.

Keskustelussa aihe herättää kiihkeitä kannanottoja sekä puolesta että vastaan. Mutta minkä puolesta ja mitä vastaan? Eri puhujat tuntuvat ymmärtävän tuloksellisuuden käsitteen sisällön eri tavoin. Tämä havainto synnyttää filosofisen mielenkiinnon. Mikä on tuloksellisuuden käsitteen merkitys kulloisellekin puhujalle? Mistä lähtökohdista puhujat näkemyksensä muodostavat? Mistä tässä ilmiössä oikeastaan on kysymys? Mitä tuloksellisuusvaatimus merkitsee kasvatuksen maailmassa, opettajan ja opiskelijan kohtaamisissa?

Kiinnostus koulutuksen tuloksellisuuden problematiikkaan nousee - aidon filosofisen ongelman tavoin - kasvatuksen käytännössä ilmen- 
neistä ristiriidoista. Oppilaitoksissa käytetään paljon aikaa siihen, että koulutuksen tulostavoitteita ja niiden mittaamisen välineitä yritetään kääntää opetuksen ja kasvatuksen kielelle. Samanaikaisesti itse opetus kärsii sekä ajallisten että taloudellisten resurssien puutteesta. Koulujen ja opetusryhmien koot kasvavat, itsenäisen opiskelun määrä lisääntyy. Säästöt karsivat opiskelijoiden valintojen mahdollisuuksia. Opettajat tuskastuvat jatkuvaan suunnitteluun, muutokseen ja mittaamiseen, koska kokevat niiden häiritsevän opetustyötä.

Tutkimustehtävä on haasteellinen, koska keskustelusta ei ole helppo saada otetta. Opetus- ja kasvatustyön näkökulmasta tulosajattelu sekoittaa asioita keskenään. Se ei tunnu erottavan olennaista epäolennaisesta eikä välineitä päämääristä. Se tarjoaa epämääräisiä keinoja ja hämärää suuntaa, se pyrkii yksinkertaistamaan monimutkaista ja muuttamaan aineelliseksi asioita, jotka perusolemukseltaan ovat enemmän henkisiä. Tuloksellisuuden nimissä koulutusta halutaan kehittää ja laatua parantaa, mutta kuka osaisi selkeästi sanoa, miksi, miten, millä tavoitteilla, välineillä ja voimavaroilla? Koulutuksessa tuloksellisuudelle ei tunnu löytyvän yhteisesti hyväksyttyä määritelmää eikä sellaisia teoreettisia perusteita, jotka kestäisivät syvällisemmän kasvatusfilosofisen tarkastelun. Kysymys ihmisen henkisestä kasvusta, sen tarvitsemasta ajasta ja rauhasta näyttävät tulosajattelussa jäävän marginaaliin.

\section{WITTGENSTEININ ARKIKIELEN FILOSOFIA MERKITYSTEN KYSYJÄNÄ}

Koulutuksen tuloksellisuuden problematiikka vei tutkimuksen lähestymistapaa ja metodologiaa etsiessä tieteenfilosofisten kysymysten äärelle. Pitkällisen pohdinnan jälkeen päädyin lähestymään asiaa merkitysanalyyttisesta näkökulmasta Ludwig Wittgensteinin (1953, 1999ab, 2004) myöhäisfilosofian kielipelin käsitettä hyväksi käyttäen.

Wittgensteinin mukaan filosofia on ennen kaikkea kielen merkityssisältöjen tutkimista. Sanojen ja käsitteiden merkitystä pohtiessaan Wittgenstein kysyy usein niiden oppimisen tilannetta. Opimme käsitteiden merkityksiä erilaisissa arjen tilanteissa samalla tavoin, kuin lapsi oppii puhumaan harjoituksen avulla. Merkitykset opitaan seuraamalla kielen käyttöön liittyvää toimintaa. Tätä arkista kielenkäyttöä Wittgenstein analysoi kielipelin, perheyhtäläisyyden ja säännön käsitteiden avulla. (Wittgenstein 1999a, Aaltola 1989.)

Sanan merkitys on sen käyttö kielessä.

(Wittgenstein 1999a, 49)

Wittgensteinin arkikielen filosofiassa (ordinary language philosophy) kielipeli tarkoittaa kieliyhteisössä syntyvää elämänmuotoa, jossa ihmiset yhteisessä toiminnassa luovat käsitteille merkityksiä. Kielipeliä voidaan verrata mihin tahansa peliin kuten shakkiin tai jalkapalloon. Pelaajat ovat vähitellen oppineet pelin idean ja säännöt ja osaavat toimia niiden mukaan. Kielipelissä tämä tarkoittaa, että puhujat ymmärtävät käyttämiensä käsitteiden merkitykset samalla tavalla ja siten suuntautuvat myös toiminnassa yhteiseen päämäärään. Kieli on aina jonkun yhteisön kieltä, puhetta jollekin (Kannisto 2002, 153). Merkitykset kiinnittyvät tiettyihin elämänmuotoihin ja niissä syntyviin kielipeleihin, ja tulevat ymmärretyksi vain niiden kautta. Kielipelit eivät muodosta mitään selkeää rakennelmaa tai kokonaisuutta, vaan ilmenevät arjen todellisuudessa päällekkäisinä ja ristikkäisinä muodostaen erilaisia verkkoja. Uusia kielipelejä syntyy, toiset vanhenevat ja jäävät pois käytöstä.

Kieli on teiden labyrintti. Tulet yhdeltä taholta ja osaat tien; tulet toiselta puolelta samaan paikkaan, etkä olekaan enää paikoista perillä. (Wittgenstein 1999a, 137.)

Filosofisen ongelman muoto on: "En ole perillä paikoista." (Wittgenstein 1999a, 91.)

Wittgenstein näkee filosofisesti mielenkiintoisina käsitteet, joiden määritelmästä ollaan epätietoisia. Hän ei kuitenkaan lähde kannattamaan sekavan käsitteen määrittelemistä, koska katsoo onnistumisen harhakuvitelmaksi. Epäselvän käsitteen taustalta ei tule löytymään sellaista yhteistä merkitystä, jonka perusteella käsitteen sisältö voitaisiin selittää. Siksi filosofian tehtävä ei ole ongelmallisen käsitteen selittäminen, vaan sen mielen, tarkoituksen etsiminen.

Merkityksen ongelma ei myöskään ratkea kaikkien merkitysten keinotekoisella yhdistämisellä. Käsite paljastuu ikään kuin sotkuiseksi lankavyyhdiksi, jota filosofi ottaa tehtäväkseen selvittää. Yrittäessään selittää tällaista sisällöltään tyhjäksi osoittautuvaa käsitettä filosofi on kuin lasipurkkiin joutunut kärpänen, joka yrittää etsiä ulospääsyä. Lentäessään valoa kohti se törmää aina lasin seinään ja hukkaa aikaansa. Ainoa reitti pääs- 
tä ulos olisi kääntyä takaisin sinne mistä tulikin. Tällä esimerkillä Wittgensteinin haluaa osoittaa, että epäselvän käsitteen merkitystä on etsittävä siitä arkisesta toiminnasta, jossa käsite on syntynyt ja jossa sitä käytetään. (von Wright 1998, 345.) On keskityttävä katsomaan arjen käytäntöä ja kielipelien ilmenemisen muotoja ja tehtävä päätelmiä niiden perusteella. (Wittgenstein 1999a, 65.)

Wittgensteinin arkikielen filosofia ei varsinaisesti pyri paljastamaan mitään uutta. Sen pyrkimys on ymmärtää paremmin jotain, jonka jo tunnemme, mutta jota emme ymmärrä tai joka meillä on taipumus ymmärtää väärin. Wittgensteinin mukaan filosofiset ongelmat johtuvat usein siitä, että meiltä puuttuu yleiskatsauksellisuus käyttämiemme käsitteiden "syväkielioppiin”. Siksi näemme käsitteiden käytön ja merkityksen vain osittain ja oletamme kaikkien muidenkin ymmärtävän asian samalla tavalla. Filosofian tehtäväksi tulee tämän puuttuvan yleiskatsauksellisuuden hahmottaminen, ts. ongelman auki purkaminen ja läpivalaisu. (Kuusela 1998.)

Wittgensteinin ajattelua seuraten pyrin hahmottamaan koulutuksen tuloksellisuuden käsitteen merkitystä kielipeleinä. Arkipäivän kielenkäyttöä tässä tarkastelussa edustaa keräämäni tekstiaineisto.

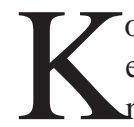

oulutuksen tuloksellisuus näyttäytyy eri elämänmuodoissa (koulutuksen hallinsessa, koulujen arjessa, elinkeinoelämässä, mediassa jne.) eri tavoin. Ei ole olemassa sellaista koulutuksen tuloksellisuuden määritelmää, jonka kaikki keskusteluun osallistuvat voisivat hyväksyä. Siitä huolimatta tuloksellisuuden vaatimus yhteiskuntaelämän keskeisenä eetoksena vaikuttaa kaikkiin koulutuksen parissa toimiviin ja muokkaa oppilaitosten toimintakulttuuria, myös opettajan suhdetta omaan työhönsä ja opiskelijoihinsa. Analyysin avulla pyrin tavoittamaan niitä merkityksiä, joita koulutuksen tuloksellisuuden käsitteelle keskustelussa annetaan tai joiden suhteen sitä kritisoidaan.

Koulutuksen tuloskeskustelun taustakonteksteina erotin aineistossa koulutuspolitiikan, pedagogiikan, median ja kasvatuksen kielipelit. Hajanaisen aineiston sain jäsennettyä kielipelien erittelyn jälkeen edelleen sisällöllisesti pienempiin kokonaisuuksiin Goffmanin kehysanalyysin ideaa ("What is it that's going on here?") hyväksi käyttäen (Goffman 1986, 8, 338-343.)
Tieteenfilosofisessa orientaatiossa päädyin kieleen liittyvän tutkimusongelman hahmottamisen kautta filosofiseen hermeneutiikkaan, joka tunnetaan ihmistieteissä "oppina” ymmärtämisestä, merkityksestä ja tulkinnasta. Ajatustani johdatti hermeneutiikan paremmin ymmärtämiseen pyrkivä tavoite. Pyrin ymmärtämään tuloksellisuuskeskustelua ja sen käsitteitä ilmiönä, jolla on omat historialliset ja yhteiskunnalliset lähtökohtansa ja juurensa. Tutkimuksen kohteena oleva todellisuus ei ole hermeneutikolle neutraalia materiaalia, vaan tietyssä merkitys- ja arvosuhteessa ilmenevää todellisuutta, jolle halutaan löytää sisältö ja mieli. Ymmärrys muotoutuu niin arjessa kuin tieteessäkin tietyssä sosiaalisessa ja kulttuurisessa todellisuudessa, josta käsin se tulisi myös tulkita. (Kusch 1986, 11-12.)

Tieteenfilosofisten ja metodologisten ratkaisujen löytyminen oli enemmän keräämäni tekstiaineiston tarkastelun ja tieteenfilosofisen kirjallisuuden lukemisen seurauksena syntynyttä vähittäistä oivallusta kuin etukäteen tehtyjen metodisten valintojen tai paradigmasitoumusten tulosta. Keskeisenä työkaluna toimi Wittgensteinin kielipelifilosofia, jonka löytyminen alkoi avata tekstimassan solmuja. Tutkimuksen rakennetta hahmotellessani käytin hyväksi Puolimatkan (1996, 14-16) esittämää filosofisen tutkimuksen vaiheistusta.

\section{TULOKSELLISUUSDISKURSSIN KIELIPELIT}

\section{Koulutuspoliittinen puhe}

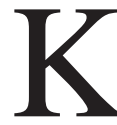

oulutuspoliittisessa puheessa tuloksellisuutta lähestytään koulutusjärjestelmän lään Iso-Britanniasta lain taloudellisuuden (economy), tehokkuuden (efficiency) ja vaikuttavuuden (effectiveness) ulottuvuuksina, joiden pohjalta sitä myös lakisääteisesti arvioidaan. Taustalla on Kuuselan $(2004,103)$ mukaan ns. New Public Management -ohjelmassa käynnistetty julkisen sektorin asiakaspalvelun laadunkehittämiseen liittyvä rakenteellinen muutos, jossa arviointi nähdään merkittävänä osana johtamista. Keskeisinä pelimerkkeinä tässä kielipelissä esiintyvät käsitteet koulutus, tehokkuus, taloudellisuus, vaikuttavuus, arviointi, kehittäminen, organisaatio, strategia, johtajuus ja laatu. Toimintaa ohjaa hallinnon määrätietoinen strategia, jonka avulla tuloksellisuuden 
käsitteistöä on pyritty juurruttamaan myös opettajien ajatteluun. Valittua strategiaa perustellaan koulutuspolitiikan tehtävällä turvata Suomen kansainvälinen kilpailukyky ja hyvinvointiyhteiskunnan säilyminen.

Koulutuspolittisen kielipelin pelaaminen eli wittgensteinilaisittain ilmaistuna säännön seuraaminen tarkoittaa tuloksellisuussanaston retorista hallintaa ja strategista käyttöä. Poliitikot, kouluhallinnon virkamiehet sekä oppilaitosten rehtorit ovat tässä pelissä keskeisessä asemassa. Myös media näyttää hallistevan kielipelin retoriset säännöt. Tekstiaineistosta nostan esimerkeiksi opetushallituksen koulutuksen tuloksellisuuden määritelmän sekä Helakorven $(2001,140)$ laatujattelua käsittelevän katkelman teoksesta Koulun johtamishaaste:

Tuloksellista koulutus on silloin, kun kansallisella ja kansainvälisellä tasolla koulutusjärjestelmän kullekin organisaatiomuodolle, oppilaitokselle ja yksilön oppimistoiminnalle asetetut tavoitteet on saavutettu.

Laadun valinnalla pyritään siis koko organisaatioon ja jokaisen toimijan kohdalla hyvin suunniteltuun ja perusteltuun, asiakkaan tarpeet mahdollisimman hyvin täyttävään, tehokkaaseen ja tulokselliseen toimintaan . - Hyvin toteutettu laatutoimintan nojaa hyviin suunnitelmiin, hyvään toteutukseen ja hyviin tuloksiin.

\section{Pedagoginen puhe}

$\mathrm{P}$ edagogisen kielipelin näen diskurssiaineistossa opetuksen näkökulmasta esitettynä opettajuuden asiantuntijapuheena, jossa tuloksellisuus ymmärretään ensisijaisesti oppimisen tuloksina. Tässä keskustelussa etsitään sekä teoreettisia perusteita että toimivia välineitä pedagogiseen kehittämistyöhön. Opetusta halutaan kehittää, jotta se tuottaisi parempia ja ajanmukaisempia tuloksia. Tuloksellisuuspuhe kääntyy puheeksi opetuksen laadusta, joka nähdään oppimisprosessin syvällisenä ymmärtämisenä ja sen lähtökohdista nousevina kehittämispyrkimyksinä. Siksi myös laaja keskustelu oppimiskäsityksestä, koulun muutoksesta ja opettajuuden uusista vaatimuksista voidaan nähdä osana tuloksellisuuskeskustelua.

Pedagogisessa puheessa tuloksellisuusajattelu siirtyy politiikan, hallinnon ja koulutusjärjestelmän tasolta koulujen arkityöhön ja pedagogi- siin suhteisiin. Tässä yhteydessä se kohtaa monia ristiriitoja esimerkiksi opetuksen sisältöjen, työtapojen valinnan ja ajankäytön painotusten suhteen. Kehittämisen muotoon puettu toiminnan tehostaminen ja jatkuva muutos tuntuvat opettajien arjessa ristiriitaisina vaatimuksina ja jatkuvana kiireenä. Julkisen kritiikin saattelemat muutosprosessit seuraavat toinen toistaan, eikä niiden todellisia vaikutuksia ehditä pohtia. Opettajat kokevat, että tulos- ja laaturetoriikka häiritsee koulun työtä eikä rauhalliselle inhimillistä kasvua tukevalle pedagogiikalle jää riittävästi aikaa (Naskali 2002; Syrjäläinen 1997, 2002).

Koetaan myös, ettei hallinnossa ja poliittisessa päätöksenteossa ymmärretä opettajan työtä. Koulutuksesta on tullut politiikan temmellyskenttä, johon eri intressiryhmät pyrkivät aktiivisesti vaikuttamaan. Pedagogisen kielipelin esimerkiksi lainaan Päivi Naskalin (2002) tekstiä Opettaja-lehdestä vuonna 2002:

Viimeaikainen keskustelu opettamisesta ja opettajuudesta on korostanut opettamisen tavoitteellista suunnittelua, tulosten mitattavuutta ja jatkuvaa itsereflektiota. Lisäksi kulttuurin raju muutos ja koulutuspolitiikan tempoileva, hätääntynyt liike ovat rakentaneet vaikeat reunaehdot kasvatus- ja opetustyölle. Konstruktivisteina me kaikki ymmärrämme, että itse tuotamme puheellamme ja teoillamme sitä maailmaa, jossa elämme. Niinpä tulos- ja laaturetoriikka on tuottanut oppilaitoksia, joissa opiskelijat kokevat välineellistyneensä, opettajat taiteilevat eri asiakasryhmien tahtojen välissä ja joissa perustyöstä on tehtävä projekti, jotta se saa oikeutuksen olla olemassa...

Pedagogisen kielipelin keskeiset kysymykset ilmenevät käsitteissä opettajuus, muutos, opetuksen laatu, oppimiskäsitys, oppimistulokset ja pedagoginen kehittäminen.

\section{Mediapuhe}

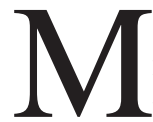

ediapuheessa koulun tuloksellisuus määrittyy toisaalta tehokkaana toiminnan järjestämisenä ja kustannussäästöinä, toisaalta hyvinä vertailtavina oppimistuloksina. Hyvää vertailtavaa tulosta pitäisi saada aikaan mahdollisimman pienillä kustannuksilla. Erityisesti koulutuksen järjestäjien puheessa asiakasajattelu ja rahasta puhuminen ovat tulleet osaksi koulutuksen arkipäivää. Koulutuksen asiakkai- 
na nähdään veronmaksajat, joilla on oikeus tietää, mitä koulutukseen käytetyt varat tuottavat. Media katsoo tehtäväkseen välittää informaatiota, jonka avulla asiakkaat voivat tehdä valintoja koulutusmarkkinoilla. Näin tuloksellisuuskeskustelu on merkinnyt oppilaitosten toimintaa koskevan julkisuuden lisääntymistä. Koulutusmarkkinoilla myönteinen julkisuus kohottaa yksittäisen oppilaitoksen imagoa ja lisää koulutukseen hakevien määrää, vastaavasti kielteinen julkisuus heikentää sen kilpailukykyä.

Tekstiaineistossa mediapuhe näyttäytyy erityisesti kunnallispolittisen päätöksenteon tasolla. Koulutuksen järjestäjien heikko taloustilanne on ajanut oppilaitokset jatkuvaan säästökierteeseen, jonka koetaan vaikeuttavan yhteiskunnan odotusten täyttämistä. Koulutuksen järjestäjien taholla koetaan, että valtio nostaa jatkuvasti opetuksellisia tulosvaatimuksia, mutta ei anna riittävästi resursseja niiden toteuttamiseen. Tässä tilanteessa opettajat ovat alkaneet nousta kapinaan jatkuvia tulosvelvoitteita vastaan. Niin koulutuspolitiikan tulos- ja laaturetoriikat kuin kasvatustieteellisten oppimisasiantuntijoiden idealistiset kehittämispuheetkin turhauttavat. Tulostavoitteisuus on alkanut uhata opettajien käsitystä työn hyvästä laaadusta. Roolinsa mukaan media pyrkii kärjistämään keskustelua. Kielipelin keskeiset sisällöt liittyvät aiheisiin oppilaitosten arki, kustannukset, säästöt, kilpailu, vertailu ja asiakkaat. Aineistoesimerkkinä lainaan katkelman ammattioppilaitoksen opettajan haastattelusta Keskipohjanmaa-lehdessä 5.3.2000 (n:o 65, 9.):

Viime vuosien aikana valtaosa budjeteista on mennyt hienojen rakennusten ja tilojen rakentamiseen, mutta nyt näissä tiloissa ei ole varaa järjestää opetusta. Miksi koulujen perustehtävään, opetukseen keskittyminen ei riitä? Liian paljon rahaa käytetään myös toimisto- ja huoltohenkilöstön kuluihin, koska on nurinkurista, että luokkia ja tiloja, joissa ei ole varaa edes järjestää opetusta, kuitenkin pidetään kaiken aikaa puhtaana. Ja aina kun leikataan, leikataan opetuksesta...

Ammatillisella puolella on puolestaan jatkuvaa "piilolomauttamista" eli viime vuosien aikana suuri osa oppitunneista on viety. Lähituntien määrä on pudonnut jopa puoleen normaalista työelämän viikkotuntimäärästä. Tämän seurauksena koulutuksen taso on laskenut ...

\section{Kasvatuspuhe}

$\mathrm{K}$ asvatuksellinen puhe merkitsee tuloksellisuuskeskustelussa yhteiskunnan arvojen kysymistä sekä koulutuksen sivistystehtävän esiinnostamista ja korostamista. Pedagogisesta kielipelistä kasvatuspuhe poikkeaa siten, että puhujina esiintyvät myös kasvatusfilosofit, kirkon edustajat ja tavalliset kansalaiset. Käytetyt käsitteet muuttuvat niin, että keskusteluun voi osallistua yli ammatti- ja koulutusrajojen. Tästä diskurssista löytyvät tuloksellisuusvaatimusten kriittisimmät puheenvuorot, joiden mukaan tuloksellisuuden kielen saapuminen koulutukseen on merkinnyt kasvatuksen kielen korvautumista markkinaideologian kielellä, joka on kyvytön keskustelemaan kouluista inhimillisen kasvun ja kasvatuksen paikkoina.

Kasvatuksen kielipeli edustaa tuloksellisuuskeskustelussa humanistista Bildung-perinnettä, jossa kasvatus ihmisyyteen nähdään koulutuksen ensisijaisena ja yhteiskunnallinen tuotantotehtävä vasta toissijaisena tavoitteena. Tehokkuuden tavoittelu ja koulutuksen tuotantotehtävän korostaminen ovat muuttaneet koulutuspolitiikan tempoilevaksi muutosten pyörteeksi, jossa ihmiset ovat saaneet välineellisen aseman. Koulutuspolitiikan käytäntö on kadottanut klassiset hyvyyden, totuuden ja kauneuden ihanteet, joidenkin mielestä pohjoismaisen hyvinvointiyhteiskunnan oikeudenmukaisuuden, tasa-arvon ja demokratian arvopäämäärätkin. Poliittisten yksilön oikeuksien turvaamiseen pyrkivä arviointi on kaventunut toiminnan tulosten arvioinniksi. Kasvatuksesta on tullut koulutusta ja koulutuspolitiikasta tuloksellisuuden arviointia. Tehokkuuden eetoksessa välineet ovat muuttuneet päämääriksi. Näin koulutuksesta on tullut täysin taloudelle alisteista (Kivirauma 2001, 77).

Kasvatuksen kielipeliin sijoitan myös uusliberalistisen koulutuspolitiikan tiukkasävyisen kritiikin, joka on voimistunut lakisääteisen arviointivelvoitteen ulottuessa yliopistojen toimintaan (esim. Hilpelä 2001, 2004ab, Simola \& Rinne 2004, 330):

Erityisesti opetusministeriön, mutta myös yliopiston rehtoreiden puhetta ovat alkaneet tahdittaa itsestäänselvyyksinä käsitteet "markkinat", "laatu", "arviointi”, "kilpailukykyisyys" ja "tulosvastuullisuus".

... Voi olla, että käsillä ovat viimeiset hetket puuttua angloamerikkalaisesta maailmasta 
tutun painajaisen vääjäämättömältä näyttävään juurtumiseen myös meille: tutkijat, opettajat ja opiskelijat valvomassa toisiaan ja itseään, kokoustelemassa ja kirjoittamassa loputtomia raporttejaan toisten ja omista tekemisistään omille ja vieraille "laatu-auditoijille" ja "vertaisasiantuntijoille", joiden pisteytysten, rankkausten ja normitusten mukaisesti laitoksia ja koulutusohjelmia kehutaan ja palkitaan, moititaan ja suljetaan.

Tämä yliopistojen sisällä virinnyt kiihkeä keskustelu merkinnee jatkossa kasvatuksen ja tutkimuksen autonomiaan liittyvän eettisen pohdinnan voimistumista ja koulutuspolitiikan kriittisen analyysin lisääntymistä.

Kasvatuksen kielipelille ominainen poleeminen sivistyspuhe sisältää sekä hermeneuttiselle kasvatusfilosofialle (Gallagher 1992) että erityisesti kriittiselle teorialle ja pedagogiikalle (esim. Habermas 1976, 1981; Giroux \& McLaren 2001; Bourdieu 1999) ominaisia kysymyksenasetteluja, joiden avulla nostetaan esiin koulutuspolitiikan taustalla vaikuttavia ideologisia riippuvuussuhteita ja analysoidaan niiden vaikutusta koulutuksen arvoihin ja päämääriin. Keskustelusta voi löytää merkkejä kasvatuksen autonomiavaatimuksesta. Tästä esimerkkinä lainaan katkelman Juha Suorannan $(1997,10-11,14)$ pamfletista Kasvatuksellisesti näkeväksi:

Monikaan ei näytä huomaavan kasvatuksen keskeistä merkitystä yhteiskuntien ja ihmisen rakentamisessa. Kasvatusfilosofeina esiintyvät tänään opetusministerit ja muut virkamiehet. Kasvattajien kaikilla tahoilla kodista ikäihmisten yliopistoihin olisi nähtävä, millaista kasvatusajattelua tästä syntyy....

Kun kasvatusajattelua johdetaan virastoista, komiteoista ja muilta virallisilta tahoilta, ollaan vaarassa hukata kokonaan kasvatuksen tärkein kohde: sinän ja minän kohtaaminen aina tämänhetkisessä ja palautumattomassa kasvatusyhteydessä....

Byrokraattisen mentaliteetin voi tavata myös kasvatuksen käytännöissä, joissa on unohdettu kysyä mikä kasvatuksessa on olennaista ja mikä ei. Peruskysymykset ovat huuhtoutuneet ulkokohtaisiin tulosvaateisiin ja arvioinnin nimissä tapahtuvaan kasvatustulosten lyhytnäköiseen mittausintoon.
DISKURSSI STRATEGISENA JA KOMMUNIKATIIVISENA

\section{TOIMINTANA}

Kielipelit muuttuvat ja diskurssi elää. Siihen voi ottaa erilaisia näkökulmia ja siitä voi löytää yhä uusia tasoja. Mielenkiintoisena havaintona voi todeta, että puhe ei välttämättä ole sidoksissa puhujan yhteiskunnalliseen tehtävään. Hallintovirkamies voi puhua kasvatuksen kielellä, poliitikko vedota kasvatustieteelliseen tutkimukseen tai toimittaja kirjoittaa kuin poliitikko. Puhe alkaa saada retorisia piirteitä, joissa kielipeliä vaihdetaan oletetun kuulijakunnan mukaan pyrkien vetoamaan päämäärän kannalta edullisimpaan ”asiantuntijaan” tai auktoriteettiin.

Mitään lopullista totuutta ei tämäntyyppisessä merkitysanalyysissä voi saavuttaa, eikä se ole filosofisen tutkimuksen tarkoitus. Koulutuksen tuloksellisuuden problematiikka on monimutkainen filosofinen ja poliittinen kysymys, jota ei voi tutkimuksen keinoin muuttaa yksinkertaiseksi, saati ratkaista. Merkitysanalyysi voi kuitenkin jäsentää keskustelua, herättää ajatuksia ja tarjota uusia näkökulmia. Itse kukin tekee asiasta omat tulkintansa, jotka väistämättä ovat hänen omiin kokemuksiinsa, elämismaailmoihinsa, intresseihinsä ja arvoihinsa sidotut.

Koulutuksen tuotantotehtävää korostava teknologinen puhe ja sivistystehtävää korostava humanistinen puhe erottuvat aineistossa selkeästi. Asian käsittely näyttää syvenevän ja sen käsitteellinen taso nousevan sitä mukaa, kun kasvatuksen arkitodellisuuteen perustuva arvokeskustelun tarve kasvaa. Puhujat joutuvat tarkastelemaan omaa näkemystään kriittisesti ja etsimään yhä vakuuttavampia perusteluja sen tueksi. Tulos- ja laaturetoriikkaan sopeutuneet ärsyyntyvät kritiikistä, jota kasvatuspuheen suunnasta esitetään. Poliittisen konsensuksen vahvistamiseen pyrkivä strateginen koulutuspuhe häiriintyy sivistyksen näkökulmasta esitetystä kommunikaation haasteesta. Tutkimuksen loppuvaiheissa ja vastaanotossa on alkanut näkyä merkkejä siitä, että myös median itsekriittisyys on heräämässä. Tältä osin tuloksellisuusdiskurssi alkaa saada piirteitä, joita Habermas (1981) kutsuu kommunikatiivisen rationaalisuuden lisääntymiseksi yhteiskunnassa.

Kommunikatiivisen toiminnan teoriassaan Habermas jakaa inhimillisen toiminnan ideaalityypit ei-sosiaaliseen ja sosiaaliseen toimintaan. En- 
sin mainitussa toiminnan kohteena on ulkoinen luonto ja se on luonteeltaan päämäärärationaalista ja välineellistä. Sosiaalisen toiminnan kohteena ovat ihmiset eli sosiaalinen todellisuus. Tämä toiminta voi Habermasin mukaan olla joko välineellisesti orientoitunutta strategista toimintaa tai ymmärrysorientoitunutta kommunikatiivista toimintaa.

Strategisessa toiminnassa toisten ihmisten päätöksiin ja toimintaan pyritään vaikuttamaan kuin luonnon objekteihin, jolloin myös kielen käytön tapa on välineellinen ja laskelmoiva. Sen sijaan kommunikatiivisessa toiminnassa pyritään aitoon yhteisymmärrykseen toisen näkemystä kunnioittavassa keskustelussa, jonka päämääränä löytää yhteinen toiminnan tapa. (Huttunen 2003, 78.) Habermasin mukaan strateginen toiminta voi olla luonteeltaan peitettyä tai avointa, ja peitetty toiminta joko systemaattisesti vääristynyttä tiedostamatonta pettämistä tai tiedostettua manipulaatiota. Strategisessa toiminnassa toimija toteuttaa päämääräänsä valitsemalla kussakin tilanteessa lupaavia välineitä ja soveltamalla niitä toiminnan kohteeseen. Keskeistä on tilanteen kontekstuaalinen tulkinta ja sen perusteella tehtävä strategia. Tässä toimintamallissa eritellään menestykseen johtavan toiminnan säännöt ja pyritään toteuttamaan niitä. Toimintaan osallistuvat omaksuvat menestykseen ja yhteisymmärrykseen suuntautuneen asenteen ja toimivat sen mukaan. Normien säätelemä toiminta edellyttää kuitenkin kaikilta asianosaisilta arvoja koskevaa yksimielisyyttä. Menestystä arvioidaan toiminnan kannattavuuden perusteella. Kielellinen kommunikaatio on strategisessa toiminnassa menestymisen väline ja toinen ihminen vaikuttamisen kohteena oleva objekti. (Habermas 1987, 72-75.)

Kommunikatiivisessa toiminnassa kieltä pidetään kommunikaatioon ja yhteisymmärrykseen tähtäävän toiminnan olennaisena osana. Toimijat ymmärretään puhujina ja kuulijoina, aitoina subjekteina. Olennaista on kommunikaatioon osallistuvien pyrkimys aitoon yhteisymmärrykseen. Toimijoilla voi olla myös yksilöllisiä päämääriä, mutta he eivät aja omaa etuaan, vaan pyrkivät harmonisoimaan toimintasuunnitelmansa yhteisen tilanteenmäärittelyn kautta. (Huttunen 1999, 155.)

Tutkimusaineiston analyysissa löydän tuloksellisuuspuheesta sekä strategisia että kommunikatiivisia piirteitä. Siinä kohtaavat koulutuspolitiikan ja hallinnon avoin strateginen, toiminnan ja tulosten tehostamiseen pyrkivä puhe sekä kasvatuksen käytännöstä ja kasvatusfilosofian piiristä nouseva toiminnan tehostamisen mieltä kysyvä kommunikatiivinen puhe. Edellisessä tulosajattelun käsitteistö on määritelty strategisesti ja jälkimmäisessä sitä pyritään sekä kasvatusfilosofiassa että arkipäivän toiminnassa hahmottamaan kommunikatiivisesti myös käytännön tasolla. Kommunikaatioon haastaa myös nykyisen koulutuspolitiikan juuria etsivä kriittinen koulutussosiologia.

Koulutuksen tuloksellisuusdiskurssin kannalta mielenkiintoinen strategisen toiminnan onnistumisen edellytys on yhteisymmärrys toiminnan arvoista ja päämääristä tai vähintään menestykseen ja yhteisymmärrykseen pyrkivä asenne. Nykyinen hallinnon ja lainsäädännön ohjaama strateginen tuloksellisuuden arviointi ei näytä täyttävän näitä edellytyksiä, koska sen käyttämä kieli ja strateginen lähestymistapa vaikeuttavat tasa-arvoisen kommunikaation syntymistä. Sen sijaan se kohtaa vakavia ristiriitoja, jotka kohdistuvat nimenomaan toiminnan taustalla oleviin arvoihin ja päämääriin.

Kommunikatiivisen toiminnan teorian sivujuonteena kehittämässään rationalisoitumisteoriassa Habermas väittää, että modernisaatio voi parantaa sekä strategista että kommunikatiivista toimintaa yhteiskunnassa. Se voi myös mahdollistaa pätevämmän tiedon ja oikeudenmukaisempien normien saavuttamisen, mitä Habermas sanoo kommunikatiivisen rationaalisuuden lisääntymiseksi yhteiskunnassa. Tällaisen järkiperäisen keskustelun vapautuminen johtuu ihmisten maailmankuvien rationalisoitumisesta ja yhteiskunnallisen moraalitietoisuuden kehittymisestä.

Kehitys muuttaa kuitenkin yhteiskuntaa yhä monimutkaisemmaksi ja vaikeammin ymmärrettäväksi, jolloin osa yhteiskunnallisesta toiminnasta siirtyy ihmisten elämismaailman horisontin ulkopuolelle. Yhteiskunnallisten järjestelmien rationaalistuminen alkaa vähitellen tuottaa seurauksia, joita järjestelmän suunnittelijat eivät tarkoittaneet eivätkä osanneet ennakoida. Järjestelmistä alkaa kehittyä omalakisiaan jatkuvassa muutoksessa olevia systeemejä, joita ihmisen on yhä vaikeampi ymmärtää. Nämä systeemit ovat vaikutuksessa toistensa kanssa rahan ja vallan mekanismien välityksellä. Modernisaatio on johtanut tilanteeseen, jossa ihmisten elämismaailmat ja yhteiskunnan järjestelmät eivät enää kohtaa. (Huttunen \& Heikkinen 1999, 173-176.) 
Tämä ilmiö saattaa kansalaiset ja erityisesti poliittiset päättäjät vaikeaan tilanteeseen. Asioiden kokonaisuudet ovat niin vaikeasti hallittavia, ettei päätösten kaikkia seuraamuksia voida enää ennakoida. Koulutuksen saralla päättäjille näyttää nykyisessä tilanteessa jäävän vain leikkausten tekijän rooli.

\section{TUULIMYLLYJÄ VASTAAN?}

Koulun tuloksellisuuden käsitteen määrittely on tapahtunut merkillisessä järjestyksessä, jos ajatellaan Wittgensteinin näkemystä siitä, kuinka käsitteen merkitys syntyy ihmisten arkisessa toiminnassa. Koulutuspoliittisessa puheessa merkitys on otettu suorana käännöksenä kulttuurisesti vieraasta kaupallisesta ympäristöstä ja sitä on lähdetty syöttämään strategisen mallin mukaan hallinnon hierarkkisessa järjestyksessä ylhäältä alas koko koulutuksen kenttään. Ongelmallisin tilanne syntyy strategisen ajattelun ja ihmisen kohtaamisessa. Johtaako tämä kohtaaminen opettajan professionaaliseen, eettiseen ristiriitaan? Humanistisille perusteille rakennettu kritiikki ei näytä vaikuttavan ilmiöön, jossa pätevät argumentit rakennetaan talouden ja teknologian kielellä. Taloudellisen tehokkuuden eetoksessa kasvattajalta tuntuu puuttuvan kieli, jolla voisi vakuuttaa kuulijansa.

Kielipelianalyysin osoittaa, että tuloksellisuuskäsitteen merkityssisältö hajoaa keskustelussa. Koulutuksen tuloksellisuudella näyttää olevan monta mieltä. Tämän monimerkityksellisyyden tiedostaminen ei häivytä ilmiön olemassaoloa. Wittgensteinin mukaan kielipelien erittely voi osoittaa kielen käyttöön liittyviä ongelmia, mutta sen avulla ei voi tehdä johtopäätöksiä - kaikki jää entiselleen. Kielipelien yhteensovittamisen problematiikkaa se ei pyri ratkaisemaan. Kuitenkin tämä konfliktuaalisuus on juuri se arkipäivän käytännön tilanne, jossa oppilaitoksissa eletään.

Miten opettajat tulostavoitteisen koulutuspolitiikan toteuttajina hahmottavat oman työnsä ja tekemisensä mielen? Tuskin kovinkaan moni ryhtyi opettajaksi tulostavoitteet saavuttaakseen. Opettajan työ koetaan edelleen kasvatuksena. Koska kaikkien toiveiden täyttäminen on vaikeaa, moni uupuu ja sairastuu. Pitäisikö tehdä strateginen valinta itsensä suojelemiseksi, sopeutua tilanteeseen ja ryhtyä tavoittelemaan vain mitattavien tulosten saavuttamista? Vai noustako barrikadeille poliittiseksi osoittautuvaan taisteluun inhimillisen työn, opetuksen ja kasvatuksen puo- lesta? Kumpaakin vaihtoehtoa näkee. Teoksessaan Autenttisuuden etiikka Charles Taylor (1995, 124-125) tarjoaa välineellisen järjen hallitsemassa markkinayhteiskunnassa kansalaisen ainoaksi vapautuksen vaihtoehdoksi eräänlaista sisäistä maanpakoa, itsensä vapaaehtoista marginaalistamista. Voiko opettaja toteuttaa tätä vapautuksen marginaalia omassa luokassaan, kaikessa rauhassa, yhdessä opiskelijoidensa kanssa? Onko suomalaisella korkeasti koulutetulla opettajalla valinnan vapautta?

\section{LÄHDE- JA TAUSTAKIRJALLISUUS}

Aaltola, J. (1989). Merkitys opettamisen ja oppimisen näkökulmasta Wittgensteinin myöhäisfilosofian ja pragmatismin valossa. Jyväskylän yliopisto. Jyväskylä Studies in Education, Psychology and Social Research 69.

Bourdieu, P. (1999). Vastatulet. Ohjeita uusliberalismin vastaiseen taisteluun. Otava.

Gadamer, H-G. (2004). Hermeneutiikka. Ymmärtäminen tieteissä ja filosofiassa. Valikoinut ja suomentanut Ismo Nikander. Vastapaino

Gallagher, S. (1992). Hermeneutics and Education. Albany: State University of New York Press.

Giroux, H. A. \& McLaren, P. (2001). Kriittinen pedagogiikka. Suom. Jyrki Vaittonen. Vastapaino.

Goffman, E. (1986). Frame Analysis. An Essay on the Organization of Experience. Boston: Northeastern University Press.

Habermas, J. (1976). Tieto ja intressi. Teoksessa Tuomela, R. \& Patoluoto, I. (toim.) Yhteiskunkuntatieteiden filosofiset perusteet I, 118-141.

Habermas, J. (1981). Theorie des kommunikativen Handelns. Bd I-II. Frankfurt am Main: Suhrkamp.

Helakorpi, S. (2001). Koulun johtamishaaste. Tammi.

Hilpelä, J. (2001). Uusliberalistisen koulutuspolitiikan aatteellinen tausta. Teoksessa Jauhiainen, A., Rinne, R. \& Tähtinen, J. (toim.) Koulutuspolitiikka Suomessa ja ylikansalliset mallit, 139-154.

Hilpelä, J. (2004a). Järjen epäilyä ja suunnittelemattomuuden ylistystä? - ekskursio uusliberalistiseen koulutuspolitiikkaan. Kasvatus 1 (35), 55-65. 
Hilpelä, J. (2004b). Kasvatusvastuusta tulosvastuuseen. Kasvatus 4 (35), 435-444.

Hirsjärvi, S. (toim.1992). Kasvatustieteen käsitteistö. Otava.

Huttunen, R. (1999). Jürgen Habermas - Kommunikatiivinen opettaminen. TeoksessaAittola, T. (toim.) Kasvatussosiologian teoreetikoita. Uudesta kasvatussosiologiasta oppimisen kriittiseen tarkasteluun, 150-181.

Huttunen, R. \& Heikkinen, H. L. T. (1999). Kriittinen teoria ja toimintatutkimus. Teoksessa Heikkinen, H. L. T., Huttunen, R. \& Moilanen, P. (toim.) Siinä tutkija missä tekijä. Toimintatutkimuksen perusteita ja näköaloja, 155-186.

Jauhiainen, A., Rinne, R. \& Tähtinen, J. (toim. 2001). Koulutuspolitiikka Suomessa jaylikansalliset mallit. Suomen Kasvatustieteellinen Seura. Kasvatusalan tutkimuksia 1.

Kannisto, H. (2002). Ymmärtäminen, kritiikki ja hermeneutiikka. Teoksessa Niiniluoto, I. \& Saarinen, E. (toim.) Nykyajan filosofia. WSOY, 303-436.

Kivirauma, J. (2001). Kansainvälistymisen pakot: Kohti eriarvoistavaa koulutuspolitiikkaa. Teoksessa Jauhiainen, A., Rinne, R. \& Tähtinen, J. (toim.) Koulutuspolitiikka Suomessa ja ylikansalliset mallit, 73-90.

Kusch, M. (1986). Ymmärtämisen haaste. Pohjoinen.

Kuusela, O. (1998). Wittgensteinin kieliopillinen filosofia. Niin \& Näin 3/98. http://www.netn. fi/398

Kuusela, P. (2004). Sosiaalisen maailman tasot ja toimijat. Esseitä sosiaalitieteiden ja arviointitutkimuksen metodologiasta. Oy UNIpress Ab.

Naskali, P. (2002). Tunteiden viisaus opetus- ja työelämässä. Opettaja nro 10, 34-36.

Opettajien mitta täyttymässä. Lomautukset, oppituntien karsiminen ja korkeakoulutavoite suututtavat. Keskipohjanmaa 5.3.2000, n:o $65,9$.

Oravakangas, A. (2005). Koulun tuloksellisuus? Filosofisia valotuksia koulun tuloksellisuuden problematiikkaan suomalaisessa yhteiskunnassa. Chydenius-instituutin tutkimuksia 2/2005. Saatavissa myös muodossa: http://www.chydenius.fi /julkaisut/julkaisu- sarjat/tekstitjul/tutkimus2_2005.pdf

Puolimatka, T. (1996). Kasvatus ja filosofia. Kirjayhtymä Oy.

Rinne, R. (2001). Koulutuspolitiikan käänne ja nuorten syrjäytyminen. Teoksessa Jauhiainen, A., Rinne, R. \& Tähtinen, J. (toim.) Koulutuspolitiikka Suomessa ja ylikansalliset mallit, 91-137.

Sahlberg, P. (1997). Opettajana koulun muutoksessa. WSOY.

Simola, H. \& Rinne, R. (2004). Laatuvallankumous, arviointiteollisuus ja korkeakoulut. Kasvatus 35 (3), 330-341.

Suoranta, J. (1997). Kasvatuksellisesti näkeväksi. Sivistyksellinen kasvatusajattelu tässä ajassa.Tampereen yliopisto. Jäljennepalvelu.

Syrjäläinen, E. (1997). Arvioinnin avulla laatua kouluihin - markkinahumua vai koulurealismia. Tampereen yliopiston opettajankoulutuslaitoksen julkaisuja A11/97.

Syrjäläinen, E. (2002). Eikö opettaja saisi jo opettaa? Koulun kehittämisen paradoksi ja opettajan työuupumus. Tampereen yliopiston opettajankoulutuslaitoksen julkaisuja A25/2002.

Taylor, C. (1995). Autenttisuuden etiikka. Suom. Timo Soukola. Gaudeamus.

Toiskallio, J. (1993). Tieto, sivistys ja käytännöllinen viisaus. Opettajan sisältötiedosta keskusteleminen postmetafyysisessä kulttuurissa. Turun yliopiston julkaisuja C99.

Toiskallio, J. (2001). Postmodernin pedagogiikka - Kuinka käy toimintakyvyn ja viisauden? Teoksessa Huhmarniemi, R., Skinnari, S. \& Tähtinen, J. (toim.) Platonista transmodernismiin, 445-470.

Wittgenstein, L. (1953) 1999a. Filosofisia tutkimuksia. Toinen painos. Suom. Heikki Nyman. WSOY.

Wittgenstein, L. (1969) 1999b. Varmuudesta. Toinen painos. Suom. Heikki Nyman. WSOY.

Wittgenstein, L. (1953) 2004. Philosophical Investigations. The German Texr, with a revised English Translation. Blackwell Publishing Ltd.

von Wright, G.H. (1998). Logiikka ja humanismi. Otava.

Artikkeli saapui toimitukseen 3.10.2005.

Se hyväksyttiin julkaistavaksi 4.11.2005. 